\title{
A Study of the Influence of Gas Channel Parameters on HT-PEM Fuel Cell Performance Using FEM Analysis
}

\author{
Viorel lonescu ${ }^{1,2}$ and Nicolae Buzbuchi ${ }^{3}$ \\ ${ }^{1}$ Department of Physics and Electronics, Ovidius University, Constanta, 900527, Romania \\ ${ }^{2}$ Doctoral School of Mechanical Engineering and Mechatronics, Maritime University, Constanta, Romania, 900663 \\ ${ }^{3}$ Department of Engineering Sciences, Maritime University, Constanta, Romania, 900663
}

\begin{abstract}
Proton Exchange Membrane Fuel Cells (PEMFC) are highly efficient power generators, achieving up to $50-60 \%$ conversion efficiency, even in sizes of a few kilowatts. Comsol Multiphysics, a commercial solver based on the Finite Element Method (FEM) was used for developing a three dimensional model of a high temperature PEMFC that can deal with both anode and cathode flow field for examining the micro flow channel with electrochemical reaction. Cathode gas flow velocity influence on the cell performance was investigated at first. Polarization curves for three different channel widths $(0.8,1.6$ and $2.4 \mathrm{~mm})$ and three different channel depths $(1,2$ and $3 \mathrm{~mm})$ were computed at a cathode inlet flow velocity of $0.06 \mathrm{~m} / \mathrm{s}$. Oxygen molar concentration at cathode catalyst layer-GDL channel interface and local current density variation along the cell length were also studied for specific gas channel geometries.
\end{abstract}

\section{Introduction}

Low temperature proton exchange membrane fuel cells(LT-PEMFCs) are in the present used as energy converters, especially for automobile applications, being used in a clean hybrid power supply system and providing the rated power to the load [1], [2]. The high capital cost of platinum catalyst layer and of pure hydrogen fuel, reduced lifetime of 5000 working hours are limiting the wide utilization of LT-PEMFC. It is also difficult to maintain proper water and thermal management, fuel cell performance being strongly affected [3,4]. High ohmic losses in the cell were observed when membrane become dehydrated as water removal rate exceeds water generation rate [5].

There are research advances of high temperature PEM fuel cells (HT-PEMFCs) with polybenzimidazole (PBI) based membrane for usage in combined heat and power generation systems ( $\mathrm{FC} \mu \mathrm{CHP}$ ) due to various reasons [6]: enhancing of the electrochemical kinetics for the cell reactions, the simple cooling system based on the increased temperature gradient between the fuel cell stack and the coolant, increasing of the $\mathrm{CO}$ tolerance which enables the utilization of lower quality reformed hydrogen.

Various studies have devoted to developing mathematical bi-dimensional models for the transport of reactants and product water in a PEMFC. Anode and cathode GDL two phase flow in the fuel cell were described by Berning and Djilali with the help of multi- phase and multi-component model, using unsaturated flow theory (UFT) [7].

The 3D HT-PEMFC numerical model used in this paper is derived from 3D single-phase isothermal model developed by E.U. Ubong et al. [8] to predict the performance of a HT-PEMFC with a PBI membrane.

The objective of this work is to investigate the effect of cathode gas flow velocity and gas channel geometry (width and height) on the cell performance with the help of a 3D model using commercial FEM package Comsol Multiphysics (version 4.2).

\section{Model Set-up}

The 3D computational domain includes a section of the PBI membrane and both cathode and anode gas flow channels, GDLs, and catalyst layers (see Fig. 1).

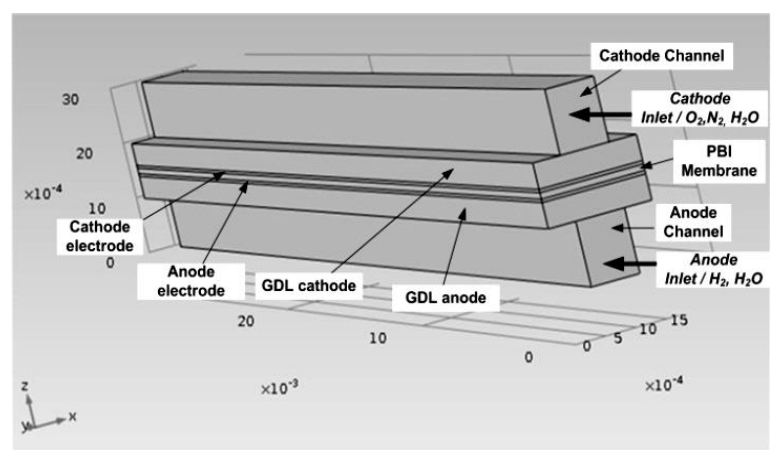

Figure 1. 3D HT-PEMFC computational model geometry. 
The operating conditions and parameters of the base model are given in Table 1 and Table 2.

Table 1. Operating parameters

\begin{tabular}{|c|c|}
\hline Parameter & Value \\
\hline \multicolumn{2}{|l|}{ Operating conditions } \\
\hline Reference pressure $(\mathrm{Pa})$ & 101325 \\
\hline Cell voltage $(\mathrm{V})$ & 0.9 \\
\hline Temperature $\left({ }^{\circ} \mathrm{C}\right)$ & 150 \\
\hline Oxygen reference concentration $\left(\mathrm{Mol} / \mathrm{m}^{3}\right)$ & 40.88 \\
\hline Hydrogen reference concentration $\left(\mathrm{Mol} / \mathrm{m}^{3}\right)$ & 40.88 \\
\hline Inlet $\mathrm{H}_{2}$ mass fraction (anode) & 0.743 \\
\hline Inlet $\mathrm{H}_{2} \mathrm{O}$ mass fraction (cathode) & 0.18 \\
\hline Inlet $\mathrm{O}_{2}$ mass fraction (cathode) & 0.228 \\
\hline \multicolumn{2}{|c|}{ Gas pair diffusivities and basic fluid parameters } \\
\hline $\mathrm{H}_{2}-\mathrm{H}_{2} \mathrm{O}$ Binary diffusion coefficient $\left(10^{-4} \mathrm{~m}^{2} / \mathrm{s}\right)$ & 1.603 \\
\hline $\mathrm{N}_{2}-\mathrm{H}_{2} \mathrm{O}$ Binary diffusion coefficient $\left(10^{-5} \mathrm{~m}^{2} / \mathrm{s}\right)$ & 4.48 \\
\hline $\mathrm{O}_{2}-\mathrm{N}_{2}$ binary diffusion coefficient $\left(10^{-5} \mathrm{~m}^{2} / \mathrm{s}\right)$ & 4.18 \\
\hline $\mathrm{O}_{2}-\mathrm{H}_{2} \mathrm{O}$ binary diffusion coefficient $\left(10^{-5} \mathrm{~m}^{2} / \mathrm{s}\right)$ & 4.91 \\
\hline Anode inlet flow velocity $(\mathrm{m} / \mathrm{s})$ & 0.17 \\
\hline Cathode inlet flow velocity $(\mathrm{m} / \mathrm{s})$ & 0.42 \\
\hline Anode viscosity $\left(10^{-5} \mathrm{~Pa} \cdot \mathrm{s}\right)$ & 1.12 \\
\hline Cathode viscosity $\left(10^{-5} \mathrm{~Pa} \cdot \mathrm{s}\right)$ & 2.68 \\
\hline
\end{tabular}

Table 2. Design parameters

\begin{tabular}{|c|c|}
\hline Parameter & Value \\
\hline \multicolumn{2}{|l|}{ Gas channel dimensions } \\
\hline Cell length $(\mathrm{cm})$ & 2 \\
\hline Channel width (mm) & 0.8 \\
\hline Channel depth (mm) & 1 \\
\hline Width of the shoulder (mm) & 0.9 \\
\hline \multicolumn{2}{|l|}{ Catalyst layer information [9] } \\
\hline Thickness $(\mu \mathrm{m})$ & 50 \\
\hline Permeability $\left(\mathrm{m}^{2}\right)$ & $2.36 \times 10^{-12}$ \\
\hline Porosity & 0.2 \\
\hline Open volume fraction for gas diffusion & 0.4 \\
\hline \multicolumn{2}{|c|}{ Membrane $\mathrm{PBI} / \mathrm{H}_{3} \mathrm{PO}_{4}$ properties [10] } \\
\hline Thickness $(\mu \mathrm{m})$ & 98 \\
\hline Conductivity (S/m) & 1.74 \\
\hline \multicolumn{2}{|l|}{ GDL properties [11] } \\
\hline Conductivity (S/m) & 222 \\
\hline Bulk porosity & 0.4 \\
\hline Permeability coefficient $\left(\times 10^{-11} \mathrm{~m}^{2}\right)$ & 1.8 \\
\hline Thickness $(\mu \mathrm{m})$ & 380 \\
\hline Conductivity (S/m) & 222 \\
\hline
\end{tabular}

At steady state, single-phase, isothermal model of PEM fuel cell consists of five principles of conservation: mass, momentum, species, energy and charge. COMSOL Multiphysics is used to solve this complex HTPEM fuel cell model. The conservation equations are solved sequentially (and grouped) for various variables, such as: velocity vector, pressure, mass/mole fraction of the species, electric and protonic phase potentials, solid and fluid - gas - phase temperatures.

Momentum transfer is modeled using Free and Porous Media Flow interface.

Laminar flow in the channels is described by the Navier-Stokes equations (dimensionless formulation), for the steady state in case of no external forces:

$$
(v \cdot \nabla) v+\nabla p-\frac{1}{R_{e}} \nabla\left(\nabla v+(\nabla v)^{T}\right)=0 ; \quad \nabla \cdot v=0
$$

where unknown depended variables are $p$ - pressure and $v$ - velocity; $\mathrm{R}_{\mathrm{e}}$ is a dimensionless Reynolds number.

Porous gas diffusion layers (GDLs) and electrode flow can be given by a similar set of differential equations, when the Brinkman formulation is used:

$$
\begin{aligned}
& k v+\nabla p-\frac{1}{R_{e}} \nabla\left(\nabla v+(\nabla v)^{T}\right)=0 \\
& \nabla \cdot v=0
\end{aligned}
$$

where $\mathrm{k}$ is the Brinkman parameter, defined as: $k=\frac{H^{2}}{R_{e} \cdot \kappa}$, with $\mathrm{H}$ - channel height and $\kappa$ - permeability.

Conservation of species was solved for the flow channels, GDLs and porous electrode using the Maxwell Stefan equations in two different Transport of Concentrated Species interfaces.

It solves for the fluxes of each species $\left(\mathrm{H}_{2}\right.$ and $\mathrm{H}_{2} \mathrm{O}$ in the anode compartment, $\mathrm{O}_{2}$ and $\mathrm{H}_{2} \mathrm{O}$ in the cathode compartment) in terms of mass fraction. The MaxwellStefan equation, defined for each component of the mixture of the three gases, is presented below [11]:

$\nabla \cdot\left[-\rho \omega_{i} \sum_{j=1}^{3} D_{i j}\left\{\frac{M}{M_{j}}\left(\nabla \omega_{j}+\omega_{j} \frac{\nabla M}{M}\right)+\left(x_{j}-\omega_{j}\right) \frac{\nabla p}{p}\right\}+\omega_{i} \rho v\right]=0$

In Eq. (3), $x_{j}$ is the molar fraction of each gas $j$, parameters $\omega_{i}$ and $\omega_{j}$ are the mass fractions of gases $i$ and $j$, respectively, parameter $\rho$ is the overall mass density of the air mixture obtained from the ideal gas law, $D_{i j}$ is the binary diffusion coefficient, $M$ is the total molar mass of the mixture and $M_{j}$ is the molecular weight of gas $j$.

Conservation of the electric charge is based on two currents: an ionic current formed by the protons travelling through the membrane and an electronic current formed by the electrons passing through the solid matrix of electrodes. The current continuity equations are obtained by using Ohm's law [8].

\section{Results and discussions}

Fig. 2 shows the effect of changing the cathode gas flow velocity at values under $0.42 \mathrm{~m} / \mathrm{s}$ on the fuel cell performance. When the gas flow velocity is increased from 0.02 to $0.12 \mathrm{~m} / \mathrm{s}$, the fuel cell performance is clearly enhanced, especially at lower operating fuel cell voltages.

The rate of the electrochemical reaction is increased due to the increase in oxygen gas through the gas diffusion layer to reaction sites. Due to the low 
membrane humidification, this enhancing performance effect is minimal at high operating voltages.

So, the air stream is able to supply oxygen with the required rate for gas flow velocity values over $0.1 \mathrm{~m} / \mathrm{s}$ in the case of the cell model with gas channel dimensions from Table 1.

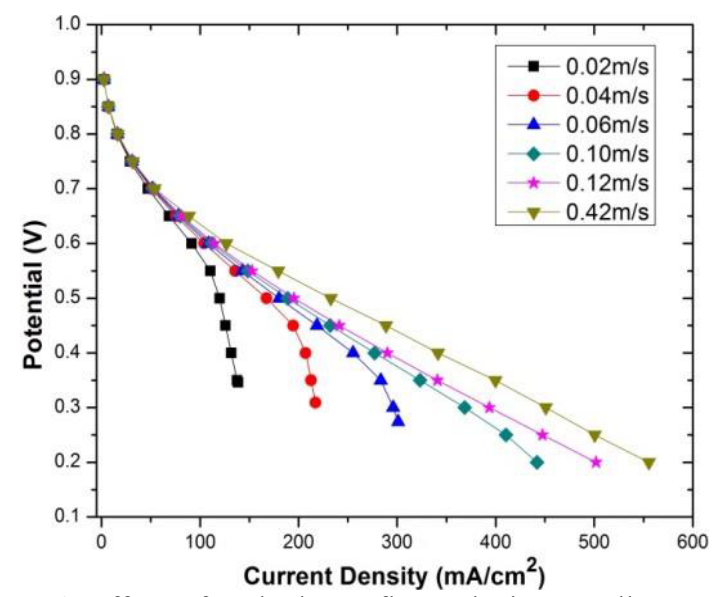

Figure 2. Effect of cathode gas flow velocity on cell performance at base conditions for different cathode inlet flow velocities (between 0.02 and $0.42 \mathrm{~m} / \mathrm{s}$ ).

Fig. 3 shows the effect of channel depth and width on the cell polarization curves for a cathode inlet flow velocity of $0.06 \mathrm{~m} / \mathrm{s}$. Cell performance was reduced to lower current densities at a channel depth of $1 \mathrm{~mm}$, with a limiting value of only $301 \mathrm{~mA} / \mathrm{cm}^{2}$ for $0.8 \times 1 \mathrm{~mm}^{2}$ geometry. So, the channel with the lowest depth presented a resistance highest enough to not be overcome by the buoyant force exerted by the fluid. With a channel depth of 2 and $3 \mathrm{~mm}$, fluid flow can take place easier through the channel and hence the cell operates at higher current densities.

For a given channel depth, the limiting current density was improved to increase in channel width. Maximum limiting current density of $484 \mathrm{~mA} / \mathrm{cm}^{2}$ at a cell voltage of $0.2 \mathrm{~V}$ was obtained with a channel width of $1.6 \mathrm{~mm}$ for a channel depth of $3 \mathrm{~mm}$.

The channel having the biggest width and lower flow resistance should induce air flowing into the channel more easily. They demonstrated that if the channel width is too big then the flow and the mass/heat transfer are also limited by the thermal boundary layer effect and the $3 \mathrm{~mm}$ gas channel with rib size and height fixed can achieve the best performance.

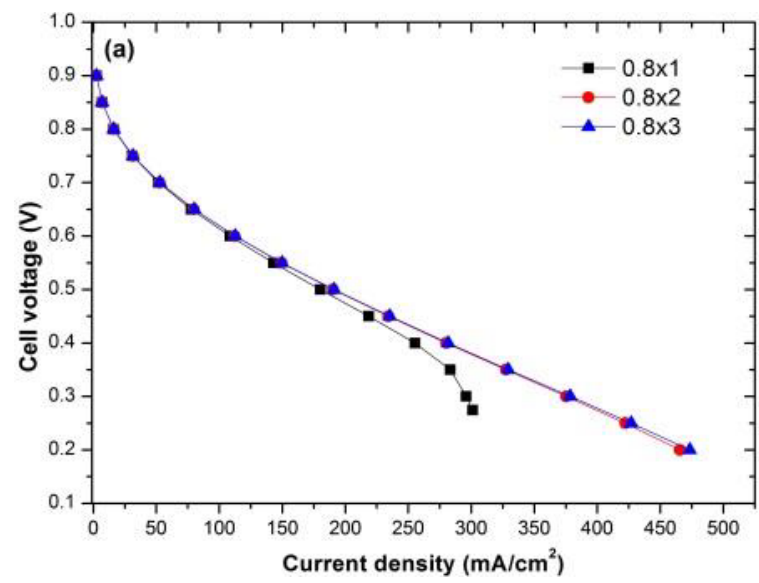

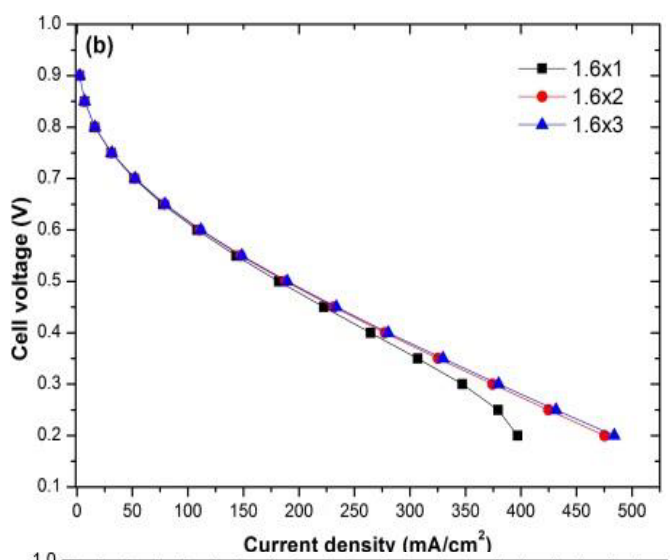

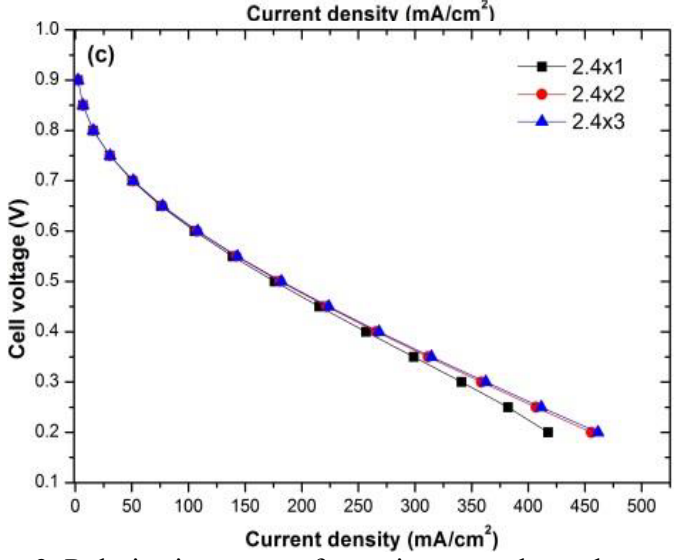

Figure 3. Polarisation curves for various gas channels geometries: a) $0.8 \times 1 \mathrm{~mm}^{2}, 0.8 \times 2 \mathrm{~mm}^{2}, 0.8 \times 3 \mathrm{~mm}^{2}$; b) $1.6 \times 1 \mathrm{~m}^{2}$, $1.6 \times 2 \mathrm{~mm}^{2}, 1.6 \times 3 \mathrm{~mm}^{2}$; c) $2.4 \times 1 \mathrm{~mm}^{2}$; $2.4 \times 2 \mathrm{~mm}^{2}, 2.4 \times 3 \mathrm{~mm}^{2}$.

Fig. 4 presented the variation of oxygen molar concentration in the cathode part of the cell model, for a channel with $1.6 \mathrm{~mm}$ width and $1 \mathrm{~mm}$ depth (see Fig. 4a) and with $1.6 \mathrm{~mm}$ width at $3 \mathrm{~mm}$ depth, respectively (see Fig. 4b). The point of interest in this figure is related to the concentration distribution in the cathode catalyst layer - GDL channel interface. Simulation was performed at a cell voltage of $0.3 \mathrm{~V}$. In Fig. $4 \mathrm{a}$ oxygen molar concentration in the gas channel and at the catalyst layer GDL channel interface is almost identical, whereas in Fig. $4 \mathrm{~b}$, we noticed that the molar concentration in the GDL gas channel interface is higher than in the catalyst layer. The cell performance is limited in both cases for various reasons: in the case (a) channel presented a higher resistance to buoyancy flow and in the case (b) porous media offered a significant diffusion resistance.

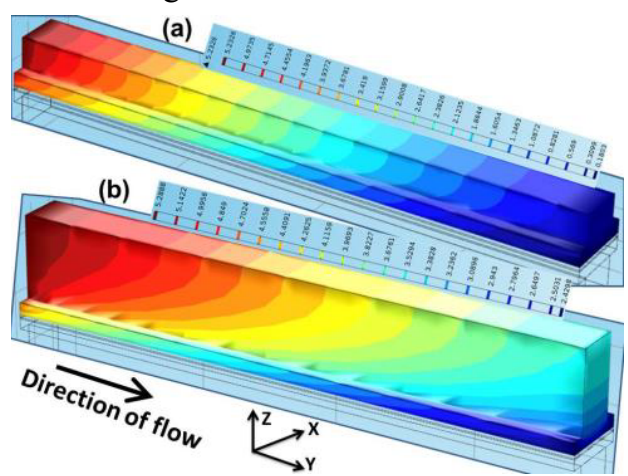

Figure 4. Distribution of the oxygen molar concentration $\left(\mathrm{Mol} / \mathrm{m}^{3}\right)$ along the cathode side of the cell for: (a) $1.6 \times 1 \mathrm{~mm}^{2}$ and (b) $1.6 \times 3 \mathrm{~mm}^{2}$ gas channel geometries at a cell voltage of $0.3 \mathrm{~V}$. 
Fig. 5a showed the local current density distribution along the cell height for a channel with $1.6 \mathrm{~mm}$ width and $1 \mathrm{~mm}$ depth at three polarization voltages. The local current production is very constant along the channel height at high voltages. At low voltages $(0.25 \mathrm{~V}$, for example) the current was generated in higher amount at the beginning of the channel, decreasing across the channel height. Due to the buoyancy effect, the oxygen concentration is more at the channel inlet and for this reason current density is high here.

Fig. 5b presented the local current density variation across the cell height at $0.3 \mathrm{~V}$ for different channel depths: 1, 2, $3 \mathrm{~mm}$. The channel width was preserved $1 \mathrm{~mm}$ for this study. It can be seen that the current production has the biggest variation for a channel depth of $1 \mathrm{~mm}$. At higher channel depths, a superior amount of oxygen enters the cathode channel.
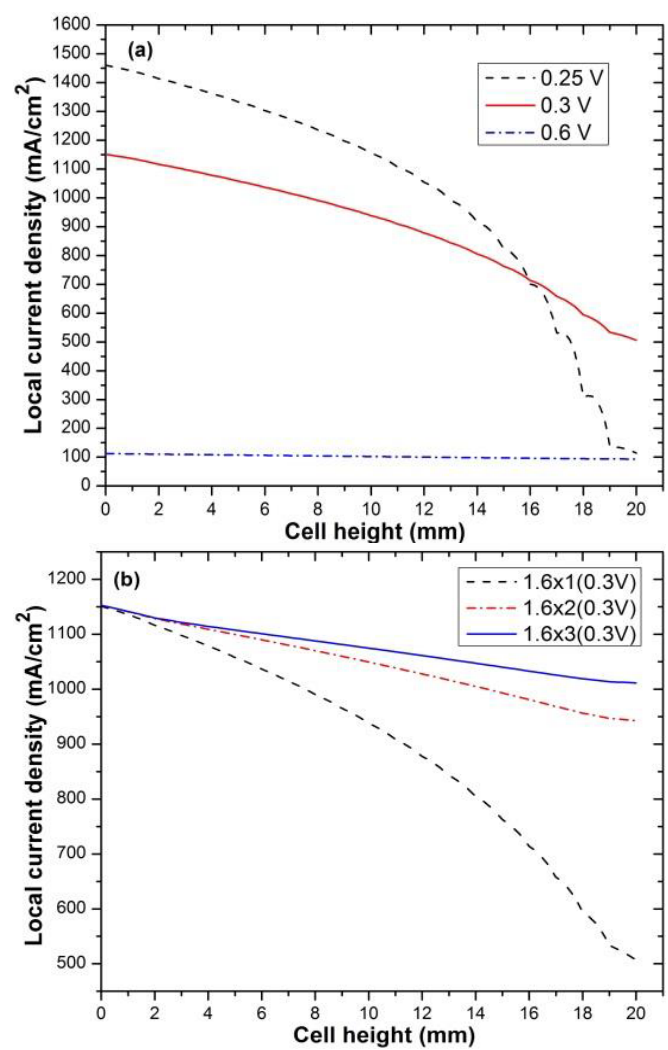

Figure 5. Local current density variation along the channel height for: a) $1.6 \times 1 \mathrm{~mm}^{2}$ channel geometry and b) $1.6 \times 1 \mathrm{~mm}^{2}$, $1.6 \times 2 \mathrm{~mm}^{2}, 1.6 \times 3 \mathrm{~mm}^{2}$ channel geometries.

\section{Conclusions}

In order the study the performance of a HT-PEM fuel cell under varying gas channel parameters, a steady-state $3 \mathrm{D}$ computational model was implemented here using Comsol Multiphysics software.

The results showed that the cathode gas flow velocity affects cell performance at values under $0.1 \mathrm{~m} / \mathrm{s}$. Optimized gas channel geometry was established from the polarization curves of the cell, at a channel width of $1.6 \mathrm{~mm}$ and channel depth of $3 \mathrm{~mm}$.

The high flow resistance given by the gas channel depth of $1 \mathrm{~mm}$ reduced the cell performance and diffusion resistance presented by the porous media in the case of $3 \mathrm{~mm}$ depth channel limited also the cell efficacy.

Local current density presented a uniform variation along the cell having an optimized gas channel geometry due to more amount of oxygen entering the channel.

\section{References}

1. F. Segura, J. M. Andujar, E. Duran, IEEE Trans. Ind. Electron. 58, 1171, (2011).

2. J. Jia, G. Wang, Y. T. Cham, Y. Wang, M. Han, IEEE Trans. Ind. Electron. 57 1945, (2010).

3. T. V. Nguyen, ECS Trans. 3, 1171, (2006).

4. H. Abtahi, A. Zilouchian, A. Saengrung, 2005 IEEE International Conference on Systems, Man and Cybernetics 4, 3486, (2005).

5. 5. G. Petrone and G. Cammarata, Modelling and Simulation, In Teach Education and Publishing, Croatia, 677, (2008).

6. J. Zhang, X. Xie, Y. Tang, C. Song, T. Navessin, Z. Shi, D. Song, H. Wang, D.P. Wilkinson, Z.S. Liu, S. Holdcroft, J. Power Sources 160, 872, (2006).

7. T. Berning, N. Djilali, J Electrochem Soc, 150, 1589, (2003).

8. E.U. Ubong, Z. Shi, X. Wang, J Electrochem Soc 156, 1276, (2009).

9. D.F. Cheddie, N.D.H. Munroe, J. Power Sources 160, 215, (2006).

10. H.L. Lin, T.L. Yu, W.K. Chang, C.P. Cheng, C.R. Hu, G.B. Jung, . Power Sources 164, 481, (2007).

11. T. Henriques, B. César, P.J. Costa Branco, Applied Energy 87, 1400, (2010). 